\title{
PENGARUH KINERJA KARYAWAN DAN MODAL DALAM MENINGKATKAN SISA HASIL USAHA PADA KOPERASI UNIT DESA BERKAH FORTUNA DI KECAMATAN MAPADECENG KABUPATEN LUWU UTARA
}

\section{SLAMET SUTOMO HADIPRAMONO, SRI WAHYUNI, SAHARUDDIN}

\begin{abstract}
ABSTRAK
Tujuan penelitian adalah untuk mengetahui dan menganalisis Pengaruh Kinerja Karyawan dan Modal Dalam Meningkatkan Sisa Hasil Usaha Pada Koperasi Unit Berkah Fortuna di Kecamatan Mapadeceng Kabupaten Luwu Utara. Penelitian yang dilakukan merupakan penelitian explanatory dan menggunakan metode survey. Populasi penelitian adalah anggota koperasi yang sekaligus dijadikan sebagai sampel yaitu sebanyak 27 sampel. Metode analisis data yang dipergunakan dalam penelitian ini adalah analisis deskriftif dan Regresi Linier Berganda, dimana variabel bebasnya yaitu kinerja karywan (X1) dan Modal Usaha (X2), variabel dependen sisa hasil usaha (Y)

Hasil penelitian dengan menggunakan analisis regresi linier berganda dengan uji F menunjukkan bahwa variabel Kinerja Karyawan (X1) dan Modal Usaha (X2) berpengaruh signifikan terhadap Sisa Hasil Usaha (Y). Sedangkan untuk uji t diketahui bahwa tingkat signifikan untuk masing-masing variabel yaitu (Kinerja Karyawan =0.000), (Modal Usaha =0,308).

Kesimpulannya bahwa satu variabel yang dapat membuktikan hipotesis yang menduga bahwa pemberian Kinerja Karyawan (X1) dan Modal Usah (X2) berpengaruh terhadap Sisa Hasil Usaha (Y) Pada Koperasi Unit Berkah Fortuna di Kecamatan Mapadeceng Kabupaten Luwu Utara yaitu variabel Kinerja Karyawan (X1), sedangkan variabel Modal Usaha (X2) tidak diterima atau tidak terbukti kebenarannya.

Kata Kunci : Kinerja Karyawan (X1), Modal Usaha (X2), dan Sisa Hasil Usaha (Y).
\end{abstract}




\section{Pendahuluan}

\section{Latar Belakang}

Mengingat kegunaan dan fungsi dari penyisihan Sisa Hasil Usaha (SHU) yang begitu banyak, maka perolehan Sisa HasiL Usaha koperasi dapat memupuk modal simpanan yaitu dengan dana cadangan yang disisihkan setiap akhir periode tutup buku, sehingga akan memperkuat struktur modalnya. Selain itu dana-dan yang disisihkan dari Sisa Hasil Usaha. Ap-abila belum dicairkan/digunakan maka akan diperlakukan sebagai tambahan modal yaitu sebagai modal pinjaman tanpa dikenakan biaya modal. Oleh sebab itu apabila koperasi dapat meningkatkan perolehan Sisa Hasil Usaha dalam setiap tahunnya dengan sendirinya akan memperkuat struktur financialnya.

Besarnya Sisa Hasil Usaha yang diperoleh koperasi disetiap tahunnya juga sebagai pertanda bahwa koperasi telah dikelola secara profesional. Pengelolaan yang profesional memerlukan sistem pertanggungjawaban yang baik serta informasi yang relevan dan dapat diandalkan. Hal itu dapat dicapai apabila koperasi sebagai badan usaha yang bergerak di bidang ekonomi melaksanakan akuntansi dalam kegiatan usahanya seperti badan usaha lainnya..

Modal koperasi terdiri dari modal simpanan dan modal pinjaman. Modal simpanan dapat berasal dari simpanan pokok, simpanan wajib, dana cadangan dan hibah. Sedangkan modal pinjaman dapat berasl dari anggota, koperasi lainnya dan atau anggotanya, bank dan lembaga keuangan lainnya, penerbitan obligasi dan surat hutan lainnya, serta sumber lain yang sah )UU No. 25 tahun Pasal 41 Ayat 1 \& 2).

Perolehan besarnya Sisa Hasil Usaha bagi koperasi menjadi sangat penting, karena dengan meningkatnya Sisa Hasil Usaha, maka akan meningkat pula kesejahteraan para anggotanya dan masyarakat pada umumnya.

Masalah yang utama dalam koperasi untuk meningkatkan Sisa Hasil Usaha selama ini adalah dalam hal permodalan, tanpa adanya modal yang cukup koperasi tidak mungkin dapat meningkatkan perolehan Sisa Hasil Usaha. Dalam hal ini modal yang dimiliki koperasi baik modal simpanan maupun modal pinjaman yang digunakan untuk menjalankan usaha akan sangat menentukan perolehan Sisa Hasil Usah. Maka dari itu KPRI harus benar-benar memperhatikan struktur finansial dan struktur modal tang efektif dalam meningkatkan perolehan Sisa Hasil Usaha.

Berdasarkan latar belakang masalh yang telah dikemukakan, maka peneliti mengambil judul penelitian tentang "Pen garuh Kinerja Karyawan dan Modal Simpanan Dalam Meningkatkan Sisa Hasil Usaha pada Koperasi Unit Desa Berkah Fortuna di Kecamatan Mapadeceg Kabupaten Luwu Utara”.

Masalah dalam penelitian ini adalah bagaiman pengembangan kinerja karyawan dan modal usaha dalam meningkatkan Sisa Hasil Usaha pada Koperasi Unit Desa Berkah Fortuna di Kecamatan Mapadeceg Kabupaten Luwu Utara?.

Tujuan penelitian ini adalah untuk mengetahui dan menganalisa mengembangkan kinerja karyawan dan modal usaha dalam meningkatkan Sisa Hasil Usaha pada 
Koperasi Unit Desa Berkah Fortuna di kecamatan Mapadeceng Kabupaten Luwu Utara.

\section{METODE PENELITIAN}

Tempat dan waktu penelitian

Dalam skripsi ini, lokasi penelitian dilakukan di Koperasi Unit Desa Berkah Fortuna di Kecamatan Mapadeceng Kabupaten Luwu Utara sebagai pelaksana program pemberian dana simpan pinjam bagi masyarakat yang membutuhkan dana pinjaman yang telah berbadan hukum dan terdaftar di Departemen Koperasi yang berlangsung pada bulan Mei 2012 .

Jenis dan Sumber Data

Penelitian mengambil data dari data primer Koperasi Unit Desa Berkah Fortuna di Kecamatan Mapadeceng Kabupaten Luwu Utara sebagai pelaksana program pemberian dana simpan pinjam bagi masyarakat yang membutuhkan dana pinjaman dan melalui interview kepada anggota/karyawan koperasi.

Populasi dan Sampel Penelitian

Populasi adalah keseluruhan subyek penelitian (Arikunto 2002). Lokasi penelitian dilakukan di Koperasi Unit Desa Berkah Fortuna di Kecamatan Mapadeceng Kabupaten Luwu Utara sebagai pelaksana program pemberian dana simpan pinjam bagi masyarakat yang membutuhkan dana pinjaman yang telah berbadan hukum dan terdaftar di Departemen Koperasi.

Metode Pengumpulan Data

Metode pengumpulan data yang digunakan dalam penelitian ini adalah: (a) Metode Interview/wawancara; Adalah sebuah dialog yang dilakukan pewawancara (interviewer) untuk memperoleh informasi dari terwawancara (Arikunto 2002). Interview yang digunakan dalam penelitian ini adalah interview terstruktu yaitu pedoman wawancara yang disusun secara terperinci sehingga menyerupai check list, (b) Metode Dokumentasi; Adalah suatu cara untuk memperoleh data atau informasi tentang hal-hal yang ada kaitannya dengan penelitian, dengan jalan melihat kembali sumber tertulis yang lalu baik berupa angka ataupun keterangan (Arikunto 2002).

Metode Analisis Data

Analisa data adalah pengolahan data yang diperoleh dengn menggunakan rumus atau aturan-aturan yang ada sesuai dengan pendekatan penelitian (Arikunto 2002). Analisa data ini dilakukan dengan tujuan untuk menguji hipotesis dalam rangka penarikan kesimpulan. (a) Deskriftif; Adalah suatu bentuk penelitian yang ditujukan untuk mendeskripsikan fenomena-fenomena yang ada, baik fenomena 
alamiah maupun fenomena buatan manusia. Fenomena itu bisa berupa bentuk, aktivitas, karakteristik, perubahan, hubungan, kesamaan, dan perbedaan antara fenomena yang satu dengan fenomena lainnya (Sukmadinata, 2006:72), (b) Analisis regresi linier berganda; Untuk mengukur besarnya pengaruh variabel bebas terhadap variabel tergantung dan memprediksi variabel tergantung dengan menggunakan variabel bebas. Dengan persamaan sebagai berikut :

$$
\begin{aligned}
& \mathrm{Y}=\mathrm{a}+\mathrm{b}_{1} \mathrm{X}+\mathrm{b}_{2} \mathrm{X}_{1}+\mathrm{b}_{2} \mathrm{X}_{2}+\mathrm{e} \\
& \text { Keterangan : } \\
& \mathrm{Y} \quad=\text { Sisa Hasil Usaha } \\
& \mathrm{X}_{1} \quad=\text { Kinerja Karyawan } \\
& \mathrm{X}_{2} \quad=\text { Modal Usaha } \\
& \mathrm{e} \quad=\text { Variabel pengganggu } \\
& \mathrm{a} \quad=\text { Konstanta } \\
& \mathrm{b}_{1,} \mathrm{~b}_{2} \quad=\text { Koefisien tiap-tiap variabel }
\end{aligned}
$$

Tabel 1

Kriteria Penerapan Sisa Hasil Usaha (SHU) Koperasi

\begin{tabular}{|l|l|l|}
\hline NO & Rentang Prosentase & Kriteria \\
\hline 1 & $80 \%-100 \%$ & Sangat Baik \\
\hline 2 & $60 \%-79 \%$ & Baik \\
\hline 3 & $40 \%-59 \%$ & Cukup Baik \\
\hline 4 & $20 \%-39 \%$ & Tidak Baik \\
\hline 5 & $0 \%-19 \%$ & Sangat Tidak BAIK \\
\hline
\end{tabular}

\section{Hasil Penelitian Dan Pembahasan}

\section{Hasil Penelitian}

Kriteria Penilaian Sisa Hasil Usaha

Sebelum melakukan pengukuran pengaruh variabel modal terhadap Sisa Hasil Usaha terlebih dahulu dilakukan penilaian kriteria (SHU) Koperasi Berkah Fortuna di Kecamatan Mappadeceng Kabupaten Luwu Utara dengan memperbandingkan nilai Rentabilitas dan Profitabilitas untuk tahun 2010 dan 2011 sebagai berikut :

\section{Tabel 2}

Total Sisa Hasil Usaha, Modal dan Pendapatan

\begin{tabular}{|l|l|l|l|}
\hline No & Keterangan & 2010 & 2011 \\
\hline 1 & Sisa Hasil Usaha & 6.851 .000 & 8.525 .000 \\
\hline 2 & Tota Modal dan Pendapatan & 94.616 .000 & 167.269 .000 \\
\hline 3 & Total Pendapatan & 85.725 .000 & 90.725 .800 \\
\hline
\end{tabular}

Sumber Data : KUD Berkah Fortuna di olah, 2012 
Hasil Uji Validitas

Uji validitas dilakukan untuk setiap variabel laten yang dikontruksi oleh indikator-indikatornya masing-masing.uji validitas digunakan untuk mengukur sah atau valid tidaknya suatu kuesioner (imam Ghozali, 2006 : 49). Uji validitas menggunakan rumus The Product. Moment Coeffisient Corelation.yaitu dengan melihat fhitung masing-masing item pertanyaan dibandingkan dengan ftabel pada tingkat signifikan $5 \%$ dan $\mathrm{df}=\mathrm{n}-2$, yaitu sebesar $27-2$ dengan menggunakan tabel Product Moment diperoleh nilai ftabel sebesar 0,381, maka apabila fhitung $>$ ftabel, maka item pertaanyaan tersebut dinyatakan valid (Santoso, $2004: 276$ ).

Hasil Uji Reliabilitas

Selain harus valid, instrumen juga harus reliabel (konsisten) instrumen dikata realibel apabila indikato-indikator tersebut memperoleh hasil-hasil yang konsisten. Suatu kuesioner dikatakan reliabel atau handal jika jawaban seseorang terhadap pernyataan adalah konsisten atau stabil. Untuk menguji reliabilitas instrumen pengukuran digunakan prosedur Cronbach's Alpha. Suatu konstruk atau variabel dikatakan reliabel jika memberikan nilai Cronbach Alpha $\geq 0,6$.

\section{Pembahasan}

Berdasarkan hasil uji $\mathrm{F}$ dalam analisis regresi liniar berganda pada penelitian ini diketahui bahwa tingkat signifikan sebesar $0,000^{\text {a }}$ lebih kecil jika dibandingkan dengan tingkat $\alpha=5 \%$ berarti bahwa variabel bebas yaitu Kinerja Karyawan (X1) dan Modal Usaha (X2) mempunyai pengaruh yang signifikan terhadap variabel dependen/variabel terikat yaitu Sisa Hasil Usaha (Y). Dengan demikian, hipotesis penelitian ini yang menduga kinerja karyawan dan modal kerja berpengaruh terhadap Sisa Hasil Usaha pada Koperasi Unit Desa Berkah Fortuna di Kecamatan Mapadeceng Kabupaten Luwu Utara adalah diterima atau terbukti kebenarannya.

\section{Penutup}

Kesimpulan dari penelitian adalah: (a) Hasil analisis menunjukkan secara simultan (Uji F) bahwa adeanya pengaru faktor variabel independen/variabel bebas yaitu kinerja karyawan (X1) dan Modal Usaha (X2) terhadap variabel dependen/variabel terikat yaitu sisa hasil usaha (Y), (b) Secara varsial (Uji t) variabel kinerja karyawan (X1) yang mempunyai pengaruh dominan terhadap Sisa Hasil Usaha, (c) Secara simultan ditunjukkan oleh nilai $\mathrm{R}$ suquare sebesar 0,618 atau 61,8\%. Hal ini berarti 61,8 \% variabel Sisa Hasil Usaha (Y) dipengaruhi oleh variabel bebas modal (X), sedangkan 0,382 atau 38,2\% sisamya di sebarkan oleh faktor-faktor lain yang tidak dijelaskan didalam model $\left(\mathrm{e}_{\mathrm{i}}\right)$. Adapun saran dari penelitian ini adalah: (a) Aspek modal usaha dilihat dari pengaruhnya terhadap Sisa 
Hasil Usaha masih belum bisa memberikan nilai maksimal sehingga harus menjadi perhatian yang diprioritaskan untuk lebih ditingkatkan lagi misalnya dengan menjalin kerjasama dengan pihak kreditur atau perbankan, (b) Adapun aspek-aspek yang berpengaruh positif dan signifikan terhadap sisa hasil usaha, hendaknya dipertahankan dan dibutuhkan kekreativan dan keinovatifan untuk terus dapat meningkatkan aspek-aspek tersebut

\section{Daftar Pustaka}

AA. Anwar Prabu Mangkunegara, 2000. Manajemen Sumber Daya Manusia. Perusahaan. Bandung : PT Remaja Rosdakarya.

Alwi, Syarafuddin, 2001. Manajemen Sumb er Daya Manusia Strategi Keunggulan. Kompetitif, BPFE, Yogyakarta.

Ambar Teguh Sulistiyani. 2003. Manajemen Sumber Daya Manusia. Edisi Pertama. Graha Ilmu. Yogyakarta

Amin Widjaja Tunggal, 1994, Akuntansi Untuk Koperasi, Rineka Cipta, jakarta.

Anonim. Undang-Undang No. 25 Tahun 1992 Tentang Perkoperasian, Arioka, Surabaya.

Arifin Sitio dan Tamba Halomoan. 2001. Koperasi: Teori dan Praktik. Jakarta: Erlangga

, Definisi, Bentuk, Peranan Dan Fungsi http ://www.koperindo.com,tanggal 27 juli 2011

Pendidikan Anggota Koperasi, diakses dari http://www.lapenkopnas.com, tanggal 27 juli 2011

Bambang Riyanto, 2001. Dasar-Dasar Pembelanjaan Perusahaan, Edisi. Keempat, Cetaakan Ketujuh, BPFE Yogyakarta, Yogyakarta

Bambang Riyanto. 2001,. Dasar-Dasar Pembelanjaan Perusahaan; Cet.7,BEP,Yogyakarta.Husein.

Hasibuan, Malayu S.P. 2005. Manajemen Sumber Daya Manusia, Edisi Revisi. Bumi Aksara, jakarta. 
Slamet Sutomo Hadipramono et al- PENGARUH KINERJA KARYAUAN DAN MODAL DALAM....

Hendar dan Kusnadi, 1999, Ekonomi Koperasi Untuk Perguruan Tinggi, Lemabaga Penerbit Fakultas Ekonomi Universitas Indonesi, Jakarta. 